\title{
Association of capillary haemangioma with bilateral hydronephrosis in an infant
}

\author{
*Umang G Thakkar ${ }^{1}$, Aruna V Vanikar ${ }^{2}$, Hargovind L Trivedi $^{1,3}$, Kalpana S Vora ${ }^{4}$, Yusuf Saifee ${ }^{5}$ \\ Sri Lanka Journal of Child Health, 2017; 46(1): 93-94 \\ DOI: http://dx.doi.org/10.4038/sljch.v46i1.8077 \\ (Key words: Capillary haemangioma, hydronephrosis, $\beta$-blocker)
}

\section{Introduction}

Capillary (or strawberry) haemangiomas are benign localized tumours of blood vessels, usually occurring in the head and neck region ${ }^{1}$. They have a malformational, hamartomatous basis and spontaneously disappear within the first few years of life ${ }^{2}$. They occur in $1-2 \%$ of all neonates and have a female: male ratio of $3: 1^{1}$. They typically arise early in life, grow rapidly during a proliferative phase and then slowly regress in an involutional phase ${ }^{1}$. We present a case of capillary haemangioma of face, neck and upper part of chest associated with bilateral hydronephrosis.

\section{Case report}

A 7 month old boy came to the outpatient clinic with his parents. He was conscious and playful, immunized according to age, with normal development. His systemic examination was unremarkable. His mother had developed gestational diabetes mellitus and she gave a history of swollen kidneys in the antenatal

${ }^{1}$ Department of Regenerative Medicine and Department of Paediatrics, ${ }^{2}$ Department of Pathology, Laboratory Medicine, Transfusion Services and Immunohaematology, ${ }^{3}$ Department of Nephrology and Transplantation Medicine, ${ }^{4}$ Department of Anaesthesiology and Critical Care Medicine, ${ }^{5}$ Department of Urology and Transplantation, G. R. Doshi and K.M. Mehta Institute of Kidney Diseases \& Research Centre - Dr. H. L. Trivedi Institute of Transplantation Sciences

*Correspondence: umangpaedia@yahoo.co.in

(Received on 01 March 2016: Accepted after revision on 22 April 2016)

The authors declare that there are no conflicts of interest

Personal funding was used for this project.

Open Access Article published under the Creative Commons Attribution CC-BY (cc) (i) License. ultrasound examination of fetus. Infant had developed a reddish skin rash (which later became hypertrophied) on lower face including left parotid region, some anterior part of neck and extending to upper part of chest from the $18^{\text {th }}$ day of life, which was diagnosed as a capillary haemangioma (Figures $1 \mathrm{~A}$ and $1 \mathrm{~B}$ ).

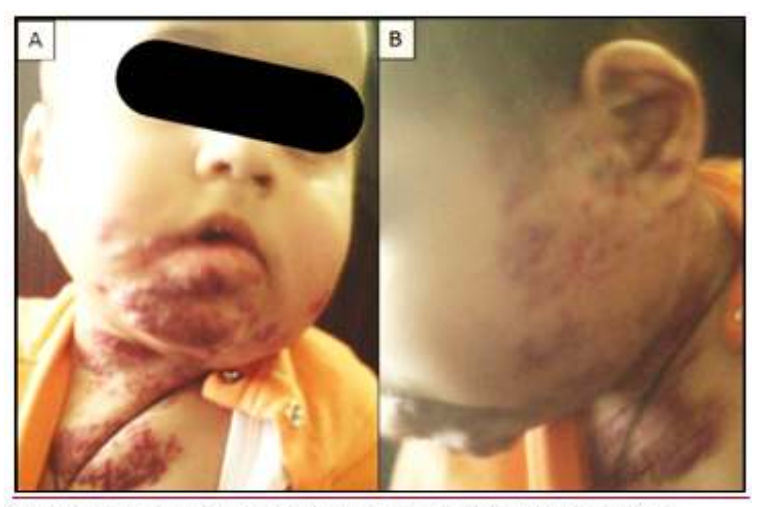

Figures 1A and 1B: Capillary haemangioma on lower face left parotid region, anterior neck and upper chest

*Permission given by parents to publish photograph

He was treated with an oral $\beta$-blocker, propranolol 1.5 $\mathrm{mg} / \mathrm{kg}$ and Timolol drops for local application on affected site. No side effects were recorded. On further evaluation, his ultrasound scan of abdomen revealed a right kidney $5.4 \times 3.0 \mathrm{~cm}$ in size and a left kidney $6.1 \times 4.1 \mathrm{~cm}$ in size at 4 months. Ultrasound examination did not reveal any intra-abdominal mass. Hence, to minimize radiation hazard to the infant, CT scan or MRI of the abdomen was not performed to rule out the possibility of intra-abdominal mass lesion. Later, bilateral hydronephrosis was confirmed by intravenous pyelography, which suggested left sided vesicoureteral junction (VUJ) obstruction and right sided pelvicalyceal ureteric junction (PUJ) obstruction (Figure 1C). Patient was surgically managed with ureteric reimplantation on left side and pyeloplasty was performed on the right side. The post-surgical course of infant was uneventful with normal renal function. 


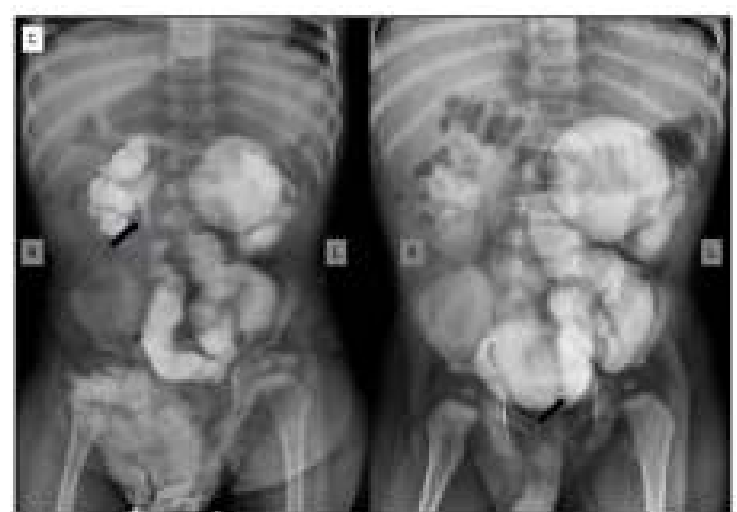

Figure 1C: (L) wesicoureteral junction obstruction and $(R)$ pelvicalyceal areteric junction obstruction indicated by arrows in intravenous pyelography

\section{Discussion}

Most haemangiomas are solitary; when multiple (with or without associated lesions in internal organs) or affecting a large segment of body, condition is known as multifocal angiomatosis ${ }^{1}$. Kasabach and Merrit reported a case of haemangioma involving skin and deep soft tissues of thigh in $1940^{3}$. Haemangiomas may present as small isolated lesions or as large masses that cause systemic symptomatology, impair vital or sensory functions or cause disfigurement, despite their self-limited course ${ }^{1}$. Their pathogenesis and optimal management remain unknown ${ }^{1}$.

Schwalb D et al reported a case of left capillary renal haemangioma which caused massive hematuria in a 27-year-old male with left hydronephrosis and nephrolithiasis without facial involvement ${ }^{4}$. Isolated cavernous haemangioma was reported in the right kidney of a newborn, who presented with moderate abdominal distension and a large abdominal mass reaching to right iliac fossa ${ }^{5}$. Rastogi $\mathrm{R}$ et al reported a vesical haemangioma at VUJ in a patient with abdominal pain secondary to hydroureteronephrosis ${ }^{6}$. Our patient had bilateral hydronephrosis with capillary haemangioma involving lower face, left parotid region, anterior part of neck and upper part of chest, an unusual co-occurrence. There was no external compression observed due to any mass producing (PUJ) obstruction and VUJ) obstruction in right and left kidney respectively in this patient. Corticosteroids are the first line of treatment for infantile capillary haemangiomas. Other options include laser therapy, interferon alfa-3, vincristine and propranolol which can inhibit the growth of these haemangiomas ${ }^{7}$.

\section{References}

1. Nandaprasad S, Sharada P, Vidya M, Karkera B, Hemanth M, Kaje C. Haemangioma - A Review. The Internet Journal of Hematology 2008 Volume 6 Number 2. Available from: http://ispub.com/IJHE/6/2/5423

2. Gangavati R, Sankpal SD, Varma SA, Kamate W. Review of hemangiomas of the oral cavity. Unique Journal of Medical and Dental Sciences 2015; 3:4-6.

3. Kasbach RH, Merritt KK. Capillary haemangioma with extensive purpura: A report of a case, American Journal of Diseases of Children 1940; 59: 1063-70 http://dx.doi.org/10.1001/archpedi.1940.019 90160135009

4. Schwalb D, Lastarria E, Park T, Mallouh C. Massive haematuria from a renal haemangioma with concomitant ureteropelvic junction obstruction. International Urology and Nephrology 1993; 25:121-7.

PMid: 8365841

5. Akel SR, Rassi A, Tawil A, Musallam S. and Akel AM. Isolated renal haemangioma in children: presentation and management. British Journal of Urology International 2002; 90:758-60. http://dx.doi.org/10.1046/j.1464410X.2002. 02890.x

6. Rastogi R, Bhargava S, Sachdeva IS, Rastogi V. Ultrasonographic diagnosis of an unusual vesical haemangioma presenting as hydroureteronephrosis. Saudi Journal of Kidney Diseases and Transplantation 2010; 21:131-134.

PMid: 20061708

7. Aletaha M, Salour H, Bagheri A, Raffati N and Amouhashemi N. Oral propranolol for treatment of paediatric capillary haemangiomas. Journal of Ophthalmic and Vision Research 2012; 7:130-3. PMid: 23275821 PMCid: PMC3520472 